\title{
USE OF ASSESSMENT FOR IMPROVING READING INSTRUCTION TO EARLY GRADE PUPILS
}

\author{
Edita Haxhijaha' \\ Primary School "Emin Duraku”, Prizren, Republic of Kosovo
}

\section{ABSTRACT}

Reading is the most important skill that every child needs to develop at school. Children who do not have good reading skills at elementary level are more likely to have limited educational progress, limited economic opportunities, and poor development in the future.

Traditional tests and assessments are lacking in this respect, because they grade pupils, based on overall score, rather than identifying the areas for improvement in order to assist teachers in more efficient planning of teaching curriculum. There is a need for a simple tool to provide pupils with various components of reading at their level. In this, the first steps are recognition of the letters of alphabet, reading of simple words, and understanding the structure of sentences and paragraphs.

This present work uses the Research in Action method to analyze the subject of using assessment for improving reading instructions for early grade pupils. The EGRA instrument, which does not provide a total result, assesses various skills and treats each skill separately. There are no overall results for EGRA, as it tests individuals. Testing of a child takes approximately $10-12$ minutes. The teacher can administer various combinations of subtests, depending on their judgement on pupils' needs. Results of every task are characterized, based on the findings related to the pupil's needs. This depends on whether the pupil is a "good reader", progressing well, or is "at risk" of failing in reading.

Research was conducted in the city of Prizren, Republic of Kosova, at the Primary and Lower Secondary School (PLSS) of "Emin Duraku", class II-3. Five pupils were involved, led by the author, as teacher of this class.

The research was conducted in cooperation with school management, teachers, and parents of the pupils involved. The collection of data was implemented within three weeks.

It is expected that this research will have positive effects on improving the results of children that find reading difficult, as well as the professional development of teachers.

This research was carried out for use in professional and scientific literature, and from the field of assessment and reading, and applying adequate scientific methods.

\section{JEL CLASSIFICATION \& KEYWORDS}

- 12 - 125 - ACTION RESEARCH - EGRA - PLANNING - READING - TESTING $=$ ASSESSMENT

\section{INTRODUCTION}

Besides writing, speaking, and listening, reading is a very important activity; it is the main source of knowledge, interconnection, and communication tool. Hence, the reading holds a special place in programs for subjects of reading and literature in school. It is necessary for teachers to know the process of reading, and teach effectively, to enable pupils to become sound readers throughout their

'editahaxhijaha@gmail.com lives, so they can be independently involved as an activity reader.

The questions are as follows: What is reading? What does it mean to read?

In fact, there is no exact definition for reading. However reading should be seen not simply as a process of identifying the printed words, but as a manufacturing act, a process in which the reader receives or gives meaning in relation to printed words

Reading remains a part of writing and reading. Many researchers point out that reading should not be identified as deciphering. However, without decoding there is no reading. The act of reading is also characterized by phonic activity (voice producing activity of sound strings) for understanding the meaning.

All reading exercises, whether analytical, synthetic, or phonetic, assist in understanding codes, either orally or written. Reading aloud has an important role in various phases, which includes the following:

a. decryption, recognition of connections between graphemes or phonemes;

b. fluent reading, connected, fast and meaningful oral reading (word sentence); and

c. expressive reading, reading, or understanding the text in its entirety (sentence with rhythm and intonation text).

Thus, to read means to form a direct meaning from that written "to read with eyes". When we read we do not even perceive letters, syllables, or words. Numerous experiments that have been done by various researchers confirm this. A simple experiment, for example, is to place several words into two columns, which involves short words ( 3 to 5 letters) in the first, and long words (10 to 12 letters) in the second, and have an the reading time of each. The time it takes for a reader to read each column is the same. Therefore, reading is more than decryption. It includes understanding the direct meaning of signs, otherwise reading these columns would be practically impossible.

Families cast the foundations of learning to read, from when the child is born. When we hear the word "assessment", we think of exams, tests, marks, stress, success, or failure.

Assessment involves a process of collecting data on pupils' knowledge. The more data we have about pupils' learning, the clearer we will understand their development and competencies, and how much they lack in learning. In addition, such information reveals the student's in the new important stage of learning.

Hence, we are referring to a product that is separate to the teaching and learning process, in terms of the Assessment of learning (Summative assessment), which pertains to understanding achievements after the learning.

Assessments during the learning process (Formative assessment) aim to inform on the job being performed in 
terms of duration and the teachers and pupils themselves towards achieving the learning goals. In this case, teachers adapt their teaching to the needs of pupils, and pupils adapt their strategies of learning for certain purposes. This use of assessment in this context, is an "assessment for learning", in contrast to the above "learning assessment", because the information it gathers aims to help students improve their performance while they are learning or applying their skills. Teachers, who see evaluation as an integral part of teaching, engage their students as collaborators in the learning process. Table 1 compares the traditional and modern evaluation processes.

Teachers can perform the assessment for learning by the following:

- involving pupils themselves (self-assessment and mutual assessment of pupils), because pupils' involvement and their responsibility for work increases their motivation to learn; and

- giving students feedback, in order to learn to improve their learning.

Figure 1 diagrammatically presents the process in assessment for learning.

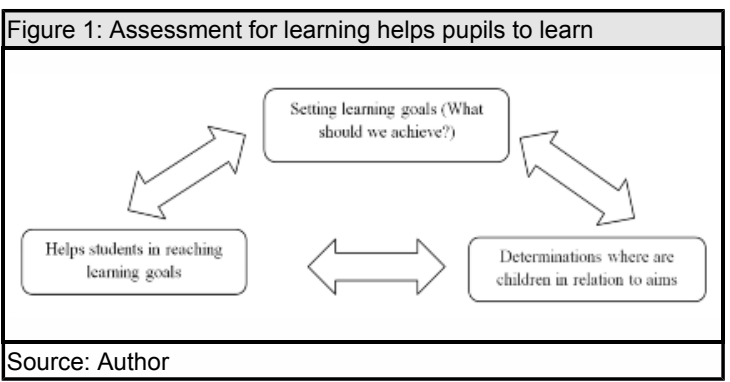

Assessment for learning aims to:

- obtain feedback information with purpose of improving learning;

- motivate pupils for further learning;

- identify strong and weak sides of pupils' (causes);

- guide pupils for future professions;

- guide pupils for individual development;

- classify, select, and assist in decision making processes:

- obtain necessary information for decision making for development and reformation of education system; and

- obtain data for research in education sciences.

\section{Literature Review}

"Opinions about the evaluation have changed in the recent years. In the new point of view, assessment and learning are two sides of the same coin" and "when pupils engage in the assessment, their learning derives precisely from that assessment," according to the National Research Council (as cited in BEP, 2013, p. 11). In addition, there is the view that there is a need for "a process of collection of data in order to take decisions for an individual or a certain group" according to Salvia \& Yssldyke (as cited in BEP, 2013, p. 15). 'A variety of methods used to measure pupils' performance and achievement including, testing, exams, assessments of practical work, oral assessment, classroom based assessments led by teachers," according to Gipps (as cited in BEP, 2013, p. 15). The Assessment Reform Group (as cited in BEP, 2013, p. 15) considered that it

\begin{tabular}{|l|l|}
\hline $\begin{array}{l}\text { Table 1: Comparison between traditional evaluation and evaluation } \\
\text { of the 21st century }\end{array}$ & Evaluation of the $\mathbf{2 1}^{\text {st }}$ century \\
\hline Traditional evaluation & Evaluation is ongoing \\
\hline $\begin{array}{l}\text { Often is provided in the written form } \\
\text { with alternative responses }\end{array}$ & Evaluation means open formats \\
\hline $\begin{array}{l}\text { The mark depends on the basis of only } \\
\text { one knowledge check }\end{array}$ & \begin{tabular}{l} 
Evaluation depends on many things \\
\hline $\begin{array}{l}\text { Instruments for evaluation are subject } \\
\text { to different norms }\end{array}$
\end{tabular} \\
\hline to different criterialuation is noted with grades \\
\hline $\begin{array}{l}\text { Success depends on the memorization } \\
\text { of information presented in certain } \\
\text { moments }\end{array}$ & $\begin{array}{l}\text { Evaluation is oriented towards the } \\
\text { progress }\end{array}$ \\
\hline $\begin{array}{l}\text { Intelligence is measured by linguistic } \\
\text { (language) and logical / mathematical } \\
\text { skills }\end{array}$ & $\begin{array}{l}\text { Intelligence is measured in solving } \\
\text { real-life problems }\end{array}$ \\
\hline $\begin{array}{l}\text { Correct answer is confirmation for } \\
\text { pupil's efforts and learning }\end{array}$ & $\begin{array}{l}\text { Pupils' views are used to understand } \\
\text { their perception with the purpose that } \\
\text { those views be included in the next } \\
\text { content learning }\end{array}$ \\
\hline $\begin{array}{l}\text { Evaluation is a separated process from } \\
\text { the teaching process }\end{array}$ & $\begin{array}{l}\text { Evaluation is linked with teaching } \\
\text { process }\end{array}$ \\
\hline Source: Author & \\
\hline
\end{tabular}

“... is a process of research and interpretation of evidences by pupils and their teachers in order to decide where are pupils, where they should reach and how in the best way will reach there. Bloom (as cited in BEP, 2013, p. 19) stated, "Formative assessment serves to gather feedback and to later correct work at each stage of the process of teaching and learning." As stated by Black (as cited in BEP, 2013, p. 19), "assessment becomes formative only when it is acted upon facts." Black, Harrision, Lee, Marshall, \& Wiliam (as cited in BEP, 2013, p. 19) stated, "every assessment that has the main purpose to serve the encouragement of pupils to learn is usually an informal assessment, embedded in all aspects of learning and teaching, and implemented by different teachers, as part of their individual teaching style." Thompson \& William (as cited in BEP, 2013, p. 19) stated,

Everything that pupils do, such as conversations in groups, answering questions, asking questions, group work, submission of homework to even the manner of how is they are seated, relaxed or confused, is information about a pupil and if they have understood or not.

A teacher, who consciously uses assessments to support learning, receives this information, analyzes it, and makes decisions that aim to fix understandings and misunderstandings that have been discovered,

"A summative assessment is referred to as collected evaluations, which usually occur at the end of every unit or certain subject, and aim to measure what pupils have learnt, or to what level they have achieved learning. Then it serves to judge their performance, based on several standards" (National Research Council (as cited in BEP, 2013, p. 19). National Council for Curriculum and Assessment (as cited in BEP, 2013 p. 19) stated that the teacher periodically identifies the achievement and progress of pupils in order to report to parents, teachers, and other relevant persons. Assessment of learning focuses more on evaluation after a short period or longer. Generally, it involves assessing pupils' learning such as, at the end of a period, of a lesson, a week, a semester or at the end of the year.

\section{Methodology}

The methods used in this study include "research in action".

"Research in action" is a research through action procedure. It is usually a collaborative activity, which often includes data from those directly affected by the research. Action research 
is used for many purposes. These include curriculum development in schools, professional development, assessment of education programs, and the development of policies and educational systems. Thus, research in action supports all teachers to find new ways to ensure quality in all activities related to teaching and learning.

"Research in action is a systematic review of professional situations, undertaken by teachers themselves, with the purpose of correcting their practices," (Eliot, 1991). Where Lawrence Stenhouse defines the research in action as "Capacity for independent professional development through studying of systematic work of teachers, studying work of other teachers and through review of pedagogic ideas through research in the classroom," (Stenhouse, 1985). During the course of the research, EGRA instrument was used. It is proven to be a useful tool in collecting data, reading standards in early grades, making teachers aware of the importance of the level of reading of their pupils, and planning teaching process based on the pupils needs.

The research was conducted during the period from 2 February until 23 February, 2015.

For the collection of data, I used personal teachers' notes (diary keeping), observations in the classroom, discussions with colleagues, cooperation with parents, and tests with pupils.

Observation during my research was planned and focused on five pupils, their actions, their involvement, and participation in the planned group activities.

The purpose and questions of research

The purpose of the research is to improve the assessment of the learning results.

The main question of the research is:

How should we evaluate in order to have success in reading the early grade pupils?

a. School context and participants

The research was conducted in the elementary school of "Emin Duraku", Prizren, Kosovo, involving five parents and five pupils. Pupils were surveyed twice during the process, once in the beginning to identify difficulties they come across while reading and in the end to see results of the action.

b. Techniques for collection of data

Pupils were tested with A-EGRA test. All pupils showed readiness to cooperate, similar to parents.

c. Planning of the research

Parents were initially informed about the goal of the research through a discussion and afterwards each was questioned about the work and success of their child.

An analysis of the data was implemented through the statistical and inductive analysis. Pupils were tested with an A-EGRA test, with seven subtests, which are considered essential during the learning of reading. These include:

- phonetic awareness (ten words, each divided into sounds);

- knowledge of letter and phonetics (hundred letters, capital and lower case, read aloud);

- reading frequent words and photography (fifty frequent words read aloud)
- reading non-words (fifty "non-words", read aloud);

- fluency in reading aloud (pupil reads aloud a text of 50-60 words, for a limited time of 60 seconds);

- reading and understanding (pupil answers questions of various levels and types of understanding related to it);

- listening and understanding (pupil listens to a short text which is read aloud, afterwards he responds regarding that texts questions at various levels);

- dictation (I read a short sentence, which the pupil writes down).

The testing of each child took 10-12 minutes

I noted the enthusiasm of pupils, which was expressed while pupils waited with impatience for the class of Albanian language.

\section{Data Analysis and Interpretation}

Since my research used research into action, I personally collected the data, and collaborated with parents and colleagues, to achieve my goal.

Measuring the level of literacy of pupils in the second grade is very easy, with the use of EGRA subtests, since these subtests show exactly the extent to which the pupil has achieved, or where there is a need to work harder to improve the level of pupils' reading. Also these subtests help in raising the self-esteem of pupils, because pupils are tested individually, and away from the eyes of their friends, which allows the children to feel comfortable and safe, without worrying that their friends will mocked them, or laugh at them for not knowing certain letters or not reading fluently.

Immediately after the first testing of pupils, various difficulties were identified in the pupils' reading. Hence, I initiated different techniques, those that assist teachers to work easily with pupils to make them better readers.

First testing of pupils

During the first testing of five pupils in the first subtest phonetic awareness, five mistakes were made. Out of five pupils tested in the second subtest Knowledge of letter and phonetics, eight mistakes were made.

Out of five pupils tested in the third subtest Reading of frequent words / photographic, 11 mistakes were made.

In the fourth subtest reading of non-words, five pupils made 37 mistakes.

In the fifth, reading and understanding, 12 mistakes were made by five tested pupils.

The five tested pupils in the six subtest Listening understanding, nine mistakes were made.

In the seventh dictation, the five tested pupils made six mistakes.

\section{Second testing of pupils}

During the second testing of five pupils in the first subtest phonetic awareness, no mistake was made.

Out of five pupils tested in the second subtest Knowledge of letter and phonetics, three mistakes were made.

Out of five pupils tested in the third subtest Reading of frequent words/photographic, six mistakes were made.

In the fourth subtest reading of non-words, five tested pupils made 13 mistakes.

In the fifth subtest reading and understanding, seven mistakes were made by five tested pupils. 
The five tested pupils in the sixth subtest listening and understanding, four mistakes were made.

In the seventh subtest, dictation, the five tested pupils made three mistakes.

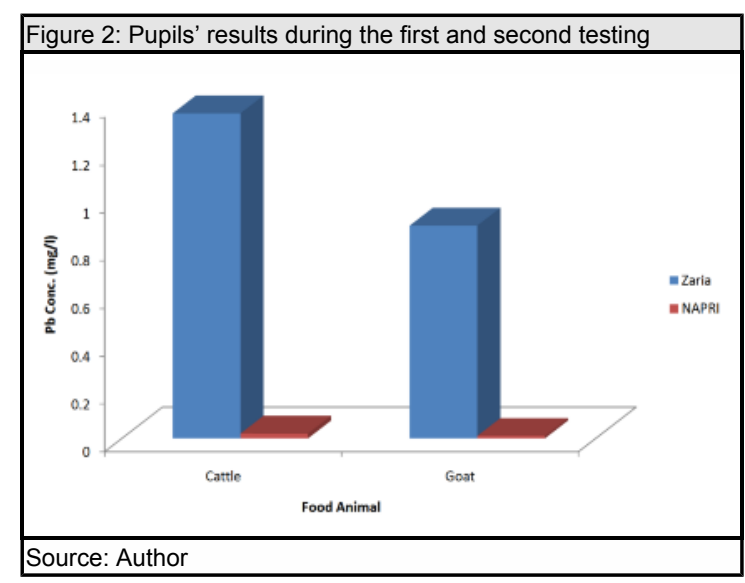

Figure 2 shows a comparison of the results.

EGRA helped me to identify, and assert precisely, the difficulties in pupils of my class, and to find where efforts should focus in order to improve outcomes, because each child had different difficulties.

\section{CONCLUSION}

The implemented method of research in action provided the desired answers for this study. It influenced the results of the research, which was conducted on the second grade classes of the elementary school.

The results showed that reading has a great effect on a child's understanding, because pupils who read fluently, understood what they read.

Consequently, teachers should concentrate more effort regarding reading, cooperating with parents. In addition, parents should set an example for their children with reading fluently.

The aim of this research is to enhance professional development of teachers to improve reading and writing skills of the second grade pupils, through various forms of cooperation.

Proper teachers' cooperation is very important in finding strategies, methods, and forms to overcome reading difficulties in pupils' who become stagnated in learning.

With implementation of this research, I realized that reading is a skill, won easily, but that different methods are needed in order to achieve the ability to read fluently.

\section{Recommendations}

- Drafters of textbooks should draft textbooks that excite the imagination of children.

- Classrooms should have reading corners with lots of books.

- An overhead projector should be used while teaching.

- Booklets should be prepared, filled with various writings.

- Parents and pre-school institutions should be made aware of the importance of reading with children and discussion about the things they read.

\section{REFERENCES}

Basic Education Program [BEP] (2013,February). Vlerësimi Informativ [Evaluation Information]. Retrived from http://bep-ks.org/ wp-content/uploads/2013/10/BEP-Vleresimi-formativ_shq.pdf

Eliot, J. (1991) Action Research for Educational Change, Milton Keynes, Open University Press; Stenhouse, L. (1985). Research as a Basis for Teaching. London: Heinemann. 